\title{
PARTISIPASI PETANI DALAM PROGRAM GERAKAN PENERAPAN PENGELOLAAN TANAMAN TERPADU PADI DI KECAMATAN KALASAN KABUPATEN SLEMAN
}

\section{Farmers Partisipation in The Movement of Implementation on Integrated Planting Management (GP-PTT) Program of Rice at Kalasan Sub District Sleman District}

\author{
${ }^{1}$ Octaviany Valentina Simanjuntak, ${ }^{2}$ Subejo, ${ }^{2}$ Roso Witjaksono \\ ${ }^{1}$ PT.Paragon \\ ${ }^{2}$ Departemen Sosial Ekonomi Pertanian, Fakultas Pertanian \\ Universitas Gadjah Mada, Yogyakarta \\ Jl. Flora 1, Bulaksumur, Yogyakarta \\ octaviany.valentina@yahoo.com
}

\begin{abstract}
GP-PTT program aims to increase rice production that is focused on the area of crops with the assistance of government facilities. As for the facilities or assistance given by the government that is seed, means of production, row planting system (legowo), and group meetings. This research was conducted in Kalasan, Sleman in order to (1) know the extent of farmer participation in the program GP-PTT rice in sub-district of Kalasan in 2015(2) know the factors related to the farmer participation in the GPPTT program in Kalasan. The method used in this research was descriptive by survey techniques. Selection of area sample was conducted purposively, while sampling farmers was conducted by simple random sampling. The total of respondents were 60 farmers. The analytical method used was the proportion test, chi-square analysis, and gamma test. The results of the research showed that the level of farmer participation in the program of GP-PTT was considered high with $71.13 \%$ initiation participation, $77.29 \%$ participation legitimacy, and $93.61 \%$ execution participation. Education is a factor that has a rather strong positive relationship with farmers' participation in the GP-PTT. Attitude and motivation are factors that hold a strong positive relationship with farmers' participation in GP-PTT. Factors that have no relation with farmers' participation in that program are age, the role of educator, chairman of farmer group, and the role of local military staff.
\end{abstract}

Keywords : Farmer, Integrated, Management, Participation, Planting

\section{INTISARI}

Program GP-PTT bertujuan untuk meningkatkan produksi padi yang difokuskan pada area tanaman dengan bantuan fasilitas pemerintah. Sedangkan untuk fasilitas atau bantuan yang diberikan oleh pemerintah yaitu benih, sarana produksi, sistem tanam garis (legowo), dan pertemuan kelompok. Penelitian ini dilakukan di Kalasan, Sleman untuk (1) mengetahui luasnya partisipasi petani dalam program padi GP-PTT di kecamatan Kalasan pada tahun 2015, (2) mengetahui faktor-faktor yang terkait dengan partisipasi petani di GP -PTT di Kalasan. Metode yang digunakan dalam penelitian ini adalah deskriptif dengan teknik survei. Pemilihan sampel daerah dilakukan secara purposive, sedangkan pengambilan sampel dilakukan secara simple random sampling. Jumlah responden sebanyak 60 petani. Metode analisis yang digunakan adalah uji proporsi, 
analisis chi-square, dan uji gamma. Hasil penelitian menunjukkan bahwa tingkat partisipasi petani dalam program GP-PTT dinilai tinggi dengan partisipasi inisiasi 71,13\%, 77,29\% legitimasi partisipasi, dan partisipasi eksekusi 93,61\%. Pendidikan merupakan faktor yang memiliki hubungan positif yang cukup kuat dengan partisipasi petani dalam program GP-PTT. Sikap dan motivasi merupakan faktor yang memiliki hubungan positif yang kuat dengan partisipasi petani dalam program GP-PTT. Faktorfaktor yang tidak berhubungan dengan partisipasi petani dalam program tersebut adalah usia, peran pendidik, ketua kelompok tani, dan peran staf militer daerah.

Kata kunci: Manajemen, Partisipasi, Penanaman, Petani, Terpadu

\section{PENDAHULUAN}

Tantangan pengadaan pangan nasional ke depan akan semakin berat mengingat banyaknya lahan irigasi subur yang terkonversi untuk kepentingan nonpertanian, sedangkan jumlah penduduk terus bertambah. Pada pihak lain, laju pertambahan produktivitas lahan sawah juga semakin menurun akibat diterapkannya teknologi yang semakin intensif tetapi jumlah pupuk yang diberikan tidaks eimbang dengan jumlah hara yang terangkut ke luar petakan berupa jerami panen atau hilang terbakar (Toha, 2007).

Berdasarkan permasalahanpermasalahan tersebut, maka kebijakan pembangunan pertanian diprioritaskan beberapa program kerja yang dijabarkan dalam beberapa kegiatan. Salah satunya adalah program ketahanan pangan.

Sejalan dengan perkembangan ilmu pengetahuan dan teknologi, Badan Litbang telah menghasilkan dan mengembangkan pendekatan Pengelolaan Tanaman Terpadu (PTT), yang ternyata mampu meningkatkan produktivitas padi serta lebih efisien. Dalam upaya pengembangan PTT secara nasional, Kementerian Pertanian meluncurkan Program Sekolah Lapang Pengelolaan Tanaman Terpadu (SLPTT). Program SL-PTT merupakan program nasional pemerintah Indonesia sejak tahun 2008. Program ini bertujuan untuk meningkatkan kemandirian pangan nasional khususnya padi. Menurut Muchtar, dkk (2014) SL-PTT merupakan salah satu strategi pemerintah untuk memberdayakan petani dalam menunjang produktivitas usahatani.

GP-PTT merupakan salah satu program yang ada dalam UPSUS (Upaya Khusus). Gerakan Penerapan Pengelolaan Tanaman Terpadu (GP-PTT), yaitu kegiatan peningkatan produktivitas akan difokuskan melalui pola kawasan yang terintegrasi dari hulu sampai hilir, peningkatan jumlah paket bantuan sebagai instrumen stimulan, serta dukungan pendampingan dan pengawalan. Terpadu dalam hal ini yakni pada proses pelaksanaannya dimana 
adanya pengawalan dan pendampingan dilakukan oleh penyuluh, babinsa, serta mahasiswa/instansi pendidikan.

Padi merupakan komoditas terpenting dari komoditas yang lainnya, karena padi adalah makanan pokok sebagian besar masyarakat di Indonesia. Pada GPPTT petani dapat langsung menerapkan teknologi budidaya spesifik lokasi yang merupakan hasil rekomendasi dari Balai Pengkajian Teknologi Pertanian (BPTP) setempat.

Dalam pelaksanaan PTT terdapat 2 komponen teknologi yang dapat diterapkan oleh petani, yaitu komponen teknologi dasar dan komponen teknologi penunjang. Komponen teknologi dasar merupakan komponan yang memiliki peranan penting dalam peningkatan hasil (Watemin, 2012).

Dalam rangka meningkatkan produksi padi dan mewujudkan swasembada pangan, Daerah Istimewa Yogyakarta telah aktif melaksanakan program Gerakan Penerapan Pengelolaan Tanaman Terpadu (GP-PTT) di 5 kabupaten/kota yaitu Kabupaten Sleman, Gunungkidul, Bantul, Kota Yogyakarta, dan Kulon Progo. Diantara lima kabupaten di Daerah Istimewa Yogyakarta, Kabupaten Sleman dan Kabupaten Kulon Progo yang mendapatkan program GP-PTT untuk komoditas padi. Kecamatan Kalasan merupakan wilayah yang cukup prospektif untuk pelaksanaan GP-PTT. Kecamatan Kalasan dipilih dalam pelaksanaan GPPTT khusus untuk komoditas padi karena letak daerah yang strategis baik sarana dan prasarana yang dibutuhkan. Keadaan tersebut menjadi suatu hal yang menarik untuk melakukan penelitian di Kecamatan Kalasan mengenai partisipasi petani dalam program GP-PTT padi.

Keberhasilan pelaksanaan Program Gerakan Penerapan Pengelolaan Tanaman Terpadu (GP-PTT) 2015 sangat ditentukan oleh partisipasi dari petani setempat secara langsung, maka partisipasi petani dalam program ini merupakan suatu hal yang sangat penting untuk dikaji. Mikkelsen (1999), menyatakan partisipasi adalah keterlibatan masyarakat dalam pembangunan diri, kehidupan, dan lingkungan mereka. Partisipasi pihak-pihak yang terlibat dianggap sebagai jalan untuk meraih kesuksesan dalam meningkatkan produksi serta mewujudkan ketahanan pangan. Sedangkan partisipasi menurut Hanafi (2004) adalah tingkat keterlibatan anggota sistem sosial dalam pengambilan keputusan.

Partisipasi petani dalam suatu kegiatan atau proyek merupakan suatu bentuk perwujudan dari besarnya penilaian 
petani atas keuntungan dibandingkan dengan biaya yang harus dikeluarkan. Partisipasi diprediksi akan terus berlanjut selama petani merasa puas atau diuntungkan dengan ikut serta dalam kegiatan tersebut (Irawan, 2011).

\section{METODE PENELITIAN}

\section{Metode Dasar}

Pelaksanaan penelitian ini dilakukan dengan menggunakan metode deskriptif analisis. Menurut Nazir (2005), metode deskriptif analisis yaitu suatu penelitan yang digunakan untuk meneliti sekelompok manusia, obyek, suatu kondisi tertentu, suatu sistem pemikiran, ataupun suatu kelas peristiwa pada masa sekarang yang kemudian dibahas secara sistematis faktual dan berdasarkan fakta-fakta yang tampak atau sebagaimana, sifat-sifat hubungan antara fenomena yang diselidik.

\section{Metode Pengambilan Sampel}

Penelitian ini dilaksanakan di Kecamatan Kalasan, Kabupaten Sleman. Pemilihan lokasi dilakukan berdasarkan pertimbangan bahwa kecamatan tersebut merupakan salah satu lokasi yang mendapatkan program Gerakan Penerapan Pengelolaan Tanaman Terpadu (GP-PTT) padi.

Sampel desa dipilih dari Kecamatan Kalasan merupakan desa yang telah melaksanakan program Gerakan Penerapan Pengelolaan Tanaman Terpadu (GP-PTT) padi. Teknik pengambilan sampel desa dilakukan secara purposive. Menurut Setiawan, teknik pengambilan sampel secara purposive adalah pemilihan sampel berdasarkan pertimbangan tertentu dengan tujuan untuk memperoleh sampel dengan karakteristik yang dikehendaki. Desa yang dipilih sebagai sampel yaitu Desa Purwo Martani, Desa Selo Martani, Desa Tirto Martani, dan Desa Taman Martani.

Pengambilan sampel petani yang diambil 60 orang petani yang aktif dan telah melaksanakan program Gerakan Penerapan Pengelolaan Tanaman Terpadu (GP-PTT) padi. Setiap desa memiliki 1 Gapoktan (Gabungan Kelompok Tani) yang didalamnya terdiri beberapa kelompok tani. Desa dan Gapoktan tersebut adalah Desa Purwo Martani (Gapoktan Purwo Makmur), Desa Selo Martani (Gapoktan Selo Makmur), Desa Tirto Martani (Gapoktan Tirto Sembodo), dan Desa Taman Martani (Gapoktan Taman Manunggal Lestari). Kemudian setiap Gapoktan dipilih secara acak 1 kelompok tani yang nantinya akan dipilih 15 petani. Pengambilan sampel petani dilakukan secara acak sederhana (Simple Random Sampling) sejumlah 15 petani dari masing-masing kelompoktani.

\section{Jenis, Sumber dan Pengumpulan Data}

Jenis data yang digunakan dalam penelitian ini adalah data primer dan data sekunder. Data primer merupakan sumber data yang diperoleh langsung dari sumber 
asli (tidak melalui media perantara). Data ini diperoleh melalui hasil wawancara dengan menggunakan kuesioner, dan melalui observasi pada responden. Data sekunder adalah data yang diperoleh dari sumber sumber lain di luar responden. Data sekunder yang digunakan adalah data yang mendukung hasil penelitian yang diperoleh baik daripihak pemerintah daerah maupun dari pasar modern yang digunakan sebagai lokasi penelitian.

\section{Metode Analisis Data}

1. Uji Proporsi

Untuk menguji hipotesis pertama, yaitu untuk mengetahui tingkat partisipasi petani dalam program GP-PTT padi 2015 di Kecamatan Kalasan Kabupaten Sleman menggunakan uji proporsi.

\section{Uji Chi-Square}

Pada hipotesis kedua, untuk mengetahui faktor-faktor internal dan eksternal yang berhubungan dengan partisipasi petani dalam program GP- PTT padi di Kecamatan Kalasan, Kabupaten Sleman digunakan uji ChiSquare. Pengujian ini dilakukan untuk mengetahui hubungan faktor internal dan faktor eksternal dengan partisipasi petani dalam program GP-PTT padi.

\section{Metode Gamma}

Chi-Square memiliki kelemahan yaitu tidak dapat mengetahui keeratan hubungan antara variabel-variabel yang diuji. Untuk menanggulangi hal ini maka dipakai suatu perhitungan koefisien kontingensi (C) secara sederhana sebagai uji lanjut dari Chi-Square. Koefisien kontingensi adalah suatu ukuran dari asosiasi yang sama bila kategori-kategori tersusun dalam barisbaris dan kolom- kolomnya.

Uji asosiasi dengan menggunakan koefisien kontingensi (C) hanya akan menunjukkan tingkat hubungan antara kedua variabel dan tidak dapat mengetahui arah hubungan berada pada arah positif atau negatif, sehingga diperlukan suatu uji tambahan untuk mengetahui untuk mengetahui arah hubungan positif ataunegatif.

Penelitian ini menggunakan uji gamma $(\gamma)$ untuk mengetahui arah hubungan. Kelebihan uji gamma yaitu tingkat ketelitiannya lebih tinggi.

\section{HASIL DAN PEMBAHASAN}

Partisipasi Petani dalam Program GPPTT Padi di Kecamatan Kalasan

Partisipasi petani dalam penelitian ini merupakan suatu proses dimana petani secara aktif terlibat dalam suatu rangkaian kegiatan, mulai dari perencanaan sampai pada pelaksanaan. Partisipasi petani diukur menggunakan tiga indikator, yaitu partisipasi inisiasi, partisipasi legitimasi, dan partisipasi eksekusi. Dengan kata lain, partisipasi petani dalam program GP-PTT padi diartikan sebagai keterlibatan petani dalam tahap inisiasi ( perencanaan kegiatan ), tahap 
legitimasi (pengambilan keputusan kegiatan) serta tahap eksekusi (pelaksanaan kegiatan).

a. Partisipasi Inisiasi

Partisipasi inisiasi adalah partisipasi yang mengundang inisiatif dari pemimpin desa, baik formal maupun informal ataupun dari anggota masyarakat mengenai suatu proyek, yang nantinya proyek tersebut merupakan kebutuhan bagi masyarakat. Tingkat partisipasi inisiasi petani dalam program GP-PTT padi dapat dilihat dalam Tabel 1.

Partisipasi Inisiasi dalam penelitian ini merupakan partisipasi petani dalam perencanaan kegiatan program GP-PTT padi yang akan dilaksanakan. Berdasarkan Tabel 1 menunjukkan bahwa tingkat partisipasi inisiasi petani secara keseluruhan sebesar $71,13 \%$. Hal ini menunjukkan bahwa tingkat partisipasi petani pada tahap inisiasi sudah cukup tinggi dalam memberikan partisipasinya dalam program GP-PTT padi. Indikator tertinggi pada partipasi inisiasi yaitu keaktifan petani menghadiri rapat koordinasi dengan penyuluh sebesar 94,00\% yang artinya hampir semua petani memiliki antusias yang tinggi dalam mengikuti program GP-PTT padi dengan aktif menghadiri rapat koordinasi bersama penyuluh. Sedangkan

Tabel 1. Partisipasi Inisiasi Petani dalam Program GP-PTT Padi di Kecamatan Kalasan

\begin{tabular}{|c|c|c|c|c|}
\hline No. & Indikator & $\begin{array}{l}\text { Interval } \\
\text { Skor }\end{array}$ & $\begin{array}{l}\text { Skor } \\
\text { Rerata }\end{array}$ & $\begin{array}{l}\text { Tingkat } \\
\text { Partisipasi } \\
(\%)\end{array}$ \\
\hline 1. & Keaktifan menghadiri penyuluhan dan rapat dengan penyuluh & $1-2$ & 1,88 & 94,00 \\
\hline 2. & $\begin{array}{l}\text { Keaktifan memberikan ide/gagasan/pendapat atas kegiatan } \\
\text { program GP-PTT padi }\end{array}$ & $1-2$ & 1,23 & 61,50 \\
\hline 3. & $\begin{array}{l}\text { Keaktifan bertanya pada saat mengikuti rapat program GP- } \\
\text { PTT padi }\end{array}$ & $1-2$ & 1,37 & 68,50 \\
\hline 4. & Keterlibatan dalam perencanaan jadwal mulai tanam padi & $1-2$ & 1,41 & 70,50 \\
\hline 5. & $\begin{array}{l}\text { Keterlibatan dalam memberi masukan mengenai varietas padi } \\
\text { yang akan ditanam }\end{array}$ & $1-2$ & 1,41 & 70,50 \\
\hline 6. & $\begin{array}{l}\text { Keterlibatan dalam memberi masukan mengenai pupuk yang } \\
\text { akan digunakan }\end{array}$ & $1-2$ & 1,51 & 75,50 \\
\hline & $\begin{array}{l}\text { Keterlibatan dalam memberi masukan mengenai cara } \\
\text { pengendalian OPT yang akan digunakan }\end{array}$ & $1-2$ & 1,38 & 69,17 \\
\hline 8. & $\begin{array}{l}\text { Keterlibatan dalam memberi masukan mengenai pestisida } \\
\text { yang digunakan }\end{array}$ & $1-2$ & 1,35 & 67,50 \\
\hline & $\begin{array}{l}\text { Keterlibatan dalam memberi masukan mengenai pola tanam } \\
\text { yang akan dipilih }\end{array}$ & $1-2$ & 1,43 & 71,67 \\
\hline 10. & Keterlibatan dalam perencanaan penetapan anggaran & $1-2$ & 1,25 & 62,50 \\
\hline & Jumlah & $1-20$ & 14,23 & 71,13 \\
\hline
\end{tabular}

Sumber : Analisis Data Primer Tahun 2015 
indikator terendah mengenai partisipasi petani pada tahap inisiasi yaitu partisipasi petani dalam memberikan ide, masukan, atau pendapat untuk kegiatan program GP-PTT yang akan dilaksanakan dengan persentase sebesar $61,50 \%$.

Beberapa petani masih ada yang ikut-ikut saja dan setuju dengan pendapat ketua atau pengurus kelompok. Beberapa petani juga ada yang memberikan masukan atau pendapat dalam partisipasi inisiasi (perencanaan), yaitu jadwal mulai tanam, varietas padi, pupuk, pestisida, dan pola tanam yang akan digunakan. Saran serta masukan yang diberikan pada jenis varietas aodi yakni varietas apdi yang menurut petani bagus dna sudah pernah digunakan sebelumnya seperti ciherang, situbangendit, IR 64, PP, dan lainnya. Kemudian beberapa petani memebrkan saran atau pupuk yang akan digunakan seperti pupuk urea, ponska, dan pupuk organik. Kemudian beberapa petani memberikan masukan untuk pestisida yang akan digunakan mudah didapatkan dan tidak terlalu mahal karena pestisida tidak disubsidi oleh pemerintah. Sebelum memberikan masukan atau pendapat untuk pola tanam, penyuluh sudah menjelaskan mengenai maisng-maisng tipe pola tanam $2:$ !, 3:1, dan 4:1. Setelah penyuluh menjelaskan pola tanam tersbeut, petani memberikan masyukan atau pendapattipe pola tanam yang akan diterapkan.

b. Partisipasi Legitimasi

Partisipasi legitimasi dalam penelitian ini adalah partisipasi pada tingkat pembicaraan atau pembuatan

Tabel 2. Partisipasi Legitimasi Petani dalam Program GP-PTT padi di Kecamatan Kalasan

\begin{tabular}{|c|c|c|c|c|}
\hline No. & Indikator & $\begin{array}{l}\text { Interval } \\
\text { Skor }\end{array}$ & $\begin{array}{l}\text { Skor } \\
\text { Rerata }\end{array}$ & $\begin{array}{l}\text { Tingkat } \\
\text { Partisipasi } \\
(\%)\end{array}$ \\
\hline 1. & Keterlibatan dalam memutuskan jadwal mulai tanam padi & $1-2$ & 1,73 & 86,67 \\
\hline 2. & Keterlibatan dalam memutuskan pelaksanaan penyiangan & $1-2$ & 1,55 & 77,50 \\
\hline 3. & $\begin{array}{l}\text { Keterlibatan dalam memutuskan jenis varietas padi yang akan } \\
\text { ditanam }\end{array}$ & $1-2$ & 1,63 & 81,67 \\
\hline 4. & $\begin{array}{l}\text { Keterlibatan dalam memutuskan jenis pupuk yang akan } \\
\text { digunakan }\end{array}$ & $1-2$ & 1,60 & 80,00 \\
\hline 5. & $\begin{array}{l}\text { Keterlibatan dalam memutuskan pola tanam yang akan } \\
\text { digunakan }\end{array}$ & $1-2$ & 1,58 & 79,17 \\
\hline 6. & $\begin{array}{l}\text { Keterlibatan dalam memutuskan cara pengendalian OPT yang } \\
\text { akan digunakan }\end{array}$ & $1-2$ & 1,40 & 70,00 \\
\hline 7. & Keterlibatan dalam memutuskan pestisida yang akan digunakan & $1-2$ & 1,52 & 75,83 \\
\hline \multirow[t]{2}{*}{8.} & $\begin{array}{l}\text { Keterlibatan dalam memutuskan penetapan anggaran dalam } \\
\text { program GP-PTT }\end{array}$ & $1-2$ & 1,35 & 67,50 \\
\hline & Jumlah & $1-16$ & 12,37 & 77,29 \\
\hline
\end{tabular}

Sumber : Analisis Data Primer Tahun 2015 
keputusan tentang suatu proyek/program, dalam hal ini adalah pembicaraan atau pengambilan keputusan tentang program Gerakan Penerapan Pengelolaan Tanaman Terpadu (GP-PTT) padi. Tingkat partisipasi legitimasi petani dalam program GP-PTT padi dapat dilihat pada table 2 .

Berdasarkan Tabel 2 dapat diketahui bahwa tingkat partisipasi legitimasi petani secara keseluruhan memiliki persentase sebesar 77,29\%. Indikator tertinggi partisipasi legitimasi petani dalam program GP-PTT padi yaitu keterlibatan dalam memutuskan jadwal mulai tanam padi dengan persentase sebesar $86,67 \%$. Hal ini menunjukkan hampir semua petani berpartisipasi dalam mengambil keputusan mengenai jadwal mulai tanam. Petani aktif dalam memutuskan jadwal mulai tanam karena petani memiliki jadwal mulai tanam yang berbeda-beda karena berkaitan dengan sistem pengairan atau irigasi yang tidak bisa serempak sehingga mereka harus memutuskan kapan mereka akan mulai tanam. Sedangkan indikator terendah partisipasi legitimasi petani dalam program GP-PTT padi, yaitu keterlibatan dalam memutuskan penetapan anggaran dalam program GP-PTT dengan persentase sebesar $67,50 \%$. Hal ini menunjukkan bahwa partisipasi petani dalam mengambil keputusan untuk menetapkan anggaran yang akan dikeluarkan cukup aktif. Namun dalam hal ini beberapa petani masih pasif untuk memberikan pendapatnya sehingga menyerahkan hasil keputusan kepada ketua maupun pengurus kelompok.

Tabel 3. Partisipasi Eksekusi Petani dalam Program GP-PTT Padi di Kecamatan Kalasan

\begin{tabular}{lllll}
\hline No. & \multicolumn{1}{c}{ Indikator } & $\begin{array}{l}\text { Interval } \\
\text { Skor }\end{array}$ & $\begin{array}{l}\text { Skor } \\
\text { Rerata }\end{array}$ & $\begin{array}{l}\text { Tingkat } \\
\text { Partisipasi } \\
(\%)\end{array}$ \\
\hline 1. & Mengeluarkan biaya dalam pelaksanaan program GP-PTT & $1-2$ & 1,12 & 56,00 \\
& padi & & \\
2. & Menanam jenis varietas padi yang disarankan & $1-2$ & 2,00 & 100,00 \\
3. & Menggunakan pupuk yang disarankan & $1-2$ & 2,00 & 100,00 \\
4. & Melakukan pemupukan secara berimbang & $1-2$ & 1,95 & 97,50 \\
5. & Melakukan penyiangan & $1-2$ & 2,00 & 100,00 \\
6. & Melakukan pengendalian OPT yang disarankan & $1-2$ & 1,98 & 99,17 \\
7. & Menggunakan pestisida & $1-2$ & 1,92 & 96,00 \\
8. & Menerapkan pola tanam jajar legowo 2:1 atau 4:1 & $1-2$ & 2,00 & 100,00 \\
9. & Melakukan panen pada waktu dan cara yang tepat & $1-2$ & 1,98 & 99,00 \\
10. & Melakukan kerja sama dengan petani yang lain dan saling & $1-2$ & 1,88 & 94,00 \\
$\quad$ sharing & & & \\
11. & Mengajak tetangga (petani lain) untuk mengikuti program & $1-2$ & 1,76 & 88,00 \\
& GP-PTT padi & & & \\
\hline
\end{tabular}

Sumber : Analisis Data Primer Tahun 2015 
c. Partisipasi Eksekusi

Partisipasi eksekusi adalah partisipasi petani pada tahap pelaksanaan kegiatan-kegiatan dalam program GPPTT padi. Tingkat partisipasi eksekusi petani dalam program GP-PTT padi dapat dilihat pada tabel 3. Partisipasi eksekusi petani pada penelitian ini menunjukkan tinggi rendahnya partisipasi petani dalam mengikuti segala kegiatan dari program GP-PTT padi.

Berdasarkan Tabel 3 menunjukkan bahwa tingkat partisipasi eksekusi petani secara keseluruhan sebesar 93,61\%. Hal ini menunjukkan bahwa tingkat partisipasi sudah termasuk tinggi dalam program GPPTT padi. Indikator tertinggi partisipasi petani pada tahap pelaksanaan yaitu menggunakan pupuk yang disarankan, menanam jenis varietas padi yang disarankan, melakukan penyiangan, dan menerapkan pola tanam jajar legowo sebesar $100,00 \%$. Hal ini menunjukkan bahwa petani memiliki partisipasi yang tinggi pada keempat indikator ini karena petani merasa tertarik dan ingin mencoba hal baru khususnya pola tanam jajar legowo dengan tujuan akan mendapatkan hasil panen yang lebih baik. Beberapa petani di Kecamatan Kalasan baru mengetahui ada pola tanam jajar legowo setelah mengikuti program GPPTT padi. Sedangkan indikator partisipasi eksekusi petani yang terendah, yaitu mengeluarkan biaya dalam pelaksanaan program GP-PTT padi dengan persentase sebesar 56,00\%. Hal ini menunjukkan bahwa beberapa petani masih mengeluarkan biaya untuk usahataninya pada program GPPTT padi. Bantuan dari pemerintah yang diberikan kepada petani sudah ditentukan jumlahnya dengan luas lahan tertentu. Sehingga petani yang memiliki luas lahan yang lebih besar masih mengeluarkan biaya lagi untuk keperluan usahataninya. Partisipasi petani dalam program GP-PTT padi di Kecamatan Kalasan dapat dilihat dari tiga indikator, yaitu inisiasi, legitimasi, dan inisiasi. Tingkat partisipasi petani secara keseluruhan dalam program GP-PTT padi dapat dilihat pada Tabel 4.

$$
\text { Berdasarkan Tabel } 4 \text { dapat }
$$
diketahui bahwa partisipasi petani

Tabel 4. Partisipasi Petani dalam Program GP-PTT Padi di Kecamatan Kalasan

\begin{tabular}{llrrr}
\hline No. & Indikator & Interval Skor & Skor Rerata & Tingkat Partisipasi (\%) \\
\hline 1. & Inisiasi & $1-20$ & 14,23 & 71,13 \\
2. & Legitimasi & $1-16$ & 12,37 & 77,29 \\
3. & Eksekusi & $1-22$ & 20,59 & 93,61 \\
\hline & Jumlah & $1-58$ & 47,19 & 81,36
\end{tabular}

Sumber : Analisis Data Primer Tahun 2015 
dalam program GP- PTT padi secara keseluruhan termasuk tinggi karena memiliki persentase sebesar $81,36 \%$. Tingkat partisipasi yang paling tinggi dimiliki oleh partisipasi eksekusi, yaitu dengan persentase sebesar 93,61\%. Hal ini menunjukkan bahwa petani antusias untuk mengikuti program GP-PTT sehingga petani aktif untuk menerapkan atau melaksanakan setiap kegiatan yang ada dalam program GP- PTT padi. Kemudian diikuti oleh partisipasi legitimasi atau pengambilan keputusan yang masuk dalam urutan kedua dengan persentase sebesar 77, 29\%. Sedangkan yang masuk urutan terakhir adalah partisipasi inisiasi atau perencanaan yang memiliki persentase sebesar $71,13 \%$. Dari Tabel 4 dapat dilihat bahwa perbedaan persentase antara partisipasi inisiasi dan partisipasi legitimasi tidak terlalu jauh. Hal ini menunjukkan bahwa secara keseluruhan partisipasi petani pada tahap inisiasi (perencanaan) dan legitimasi (pengambilan keputusan) sudah cukup tinggi. Walaupun begitu, masih ada beberapa anggota petani yang masih bersifat pasif pada kedua tahap ini.

Berdasarkan penelitian Winata (2012) dengan masih rendahnya tingkat partisipasi petani dalam perencanaan dan evaluasi program maka diperlukan sebuah program yang dapat mendorong petani untuk lebih aktif terlibat dalam perencanaan dan evaluasi. Caranya adalah dengan pendekatan persuasive kepada petani agar petani lebih sering mneghadiri rapat kelompok. Di dalam rapat kelompok dapat disampaikan materi yang dapat memotivasi petani untuk lebih aktif terlibat dalam perencanaan dan evaluasi.

Analisis selanjutnya yaitu mengetahui sebaran petani berdasarkan partisipasinya. Analisis ini dibagi menjadi 3 kategori, yaitu rendah, sedang, dan tinggi. Kategori partisipasi petani tergolong rendah apabila memiliki skor 0-19, kategori sedang apabila memiliki skor 20-40, sedangkan untuk kategori tinggi apabila memiliki skor 41-58. Sebaran partisipasi petani dapat dilihat pada Tabel 5.

Tabel 5. Sebaran Petani Berdasarkan Partisipasi dalam Program GP-PTT Padi di KecamatanKalasan

\begin{tabular}{llrr}
\hline No. & Kategori (Skor) & Jumlah (jiwa) & Persentase $(\%)$ \\
\hline 1. & Rendah (0-19) & 0 & 0 \\
2. & Sedang (20-40) & 18 & 30 \\
3. & Tinggi (41-58) & 42 & 70 \\
\hline & Jumlah & 60 & 100 \\
\hline
\end{tabular}

Sumber : Analisis Data Primer Tahun 2015 
Berdasarkan Tabel 5 dapat diketahui bahwa partisipasi petani dalam program GP- PTT padi tergolong tinggi dengan persentase $70 \%$ atau sebanyak 42 petani dan termasuk dalam kategori sedang sebesar 30\% atau sebanyak 18 petani. Hal ini menunjukkan bahwa petani memberikan partisipasi yang cukup tinggi dalam program GP-PTT padi. Partisipasi yang cukup tinggi diberikan oleh petani juga dikarenakan keinginan petani untuk meningkatkan hasil produksi usahataninya dan menambah penghasilan keluarga.

Hipotesis pertama pada penelitian ini diduga sebagian besar petani di Kecamatan Kalasan (>50\%) memiliki partisipasi yang tinggi dalam program GP-PTT padi. Untuk membuktikan tingkat partisipasi petani dalam program GP-PTT padi, maka dapat diuji dengan menggunakan uji proporsi. Adapun langkah-langkah uji proporsi adalah:

a. Pengujian hipotesis

$$
\begin{aligned}
& \text { Ho }: \mathrm{P} \leq 50 \% \\
& \text { Ha }: \mathrm{P}>50 \%
\end{aligned}
$$

Dengan pengertian :

Ho : Diduga kurang dari atau sama dengan $50 \%$ petani di Kecamatan Kalasan memiliki partisipasi yang tinggi dengan adanya program GP-PTT padi.

Ha : Diduga lebih dari $50 \%$ petani di Kecamatan Kalasan memiliki partisipasi yang tinggi dengan adanya program GP-PTT padi. b. Tingkat signifikansi pada $\alpha=10 \%(0,1), x=42, n=60$, Po $=50 \%$ po : koefisien keyakinan (50\%) $\mathrm{x}$ : jumlah sampel yang mempunyai partisipasi tinggi dalam program GP- PTT padi di Kecamatan Kalasan, Kabupaten Sleman

$\mathrm{n}$ : jumlah keseluruhan sampel

c. Statistik pengujian

$\mathrm{Z}=\frac{\frac{x}{n}-P_{o}}{\sqrt{\frac{P o(1-P O)}{n}}}$

$$
Z=\frac{\frac{42}{60}-0,5}{\sqrt{\frac{0,5(1-0,5)}{60}}}
$$

$$
Z=\frac{0,2}{0,0645}
$$

Zhitung $=3,10$

Ztable $=-1,28$

d. Kriteria pengujian

1) $Z$ hit lebih besar dari $Z$ tabel, Ho ditolak, Ha diterima sehingga hipotesis yang diajukan diterima.

2) Z hit lebih kecil atau sama dengan $\mathrm{Z}$ tabel, Ha ditolak, Ho diterima sehingga hipotesis yang diajukanditolak. Kesimpulan Zhitung $=3,10$ Ztabel $=-1,28$ 
Zhitung $\geq$ Ztabel, $\mathrm{H}_{0}$ ditolak, $\mathrm{H}_{\mathrm{a}}$ diterima sehingga hipotesis yang diajukan diterima.

Berdasarkan hasil perhitungan menggunakan uji proporsi, diperoleh Zhitung sebesar 3,10. Hasil uji proporsi lebih besar daripada Ztabel yaitu -1,28. Hal ini menunjukkan bahwa hipotesis pertama (Ha) diterima sehingga dapat disimpulkan bahwa lebih dari 50\% anggota kelompok tani memiliki partisipasi yang tinggi dalam program GP-PTT padi.

Faktor-Faktor yang Berhubungan dengan Partisipasi Petani dalam Program GP-PTT Padi di Kecamatan Kalasan

Partisipasi petani dalam program GP- PTT padi memiliki hubungan dengan beberapa faktor, yaitu faktor internal dan faktor eksternal. Tujuan penelitian yang kedua adalah untuk mengetahui faktor-faktor apa saja yang berhubungan dengan partisipasi petani dalam program GP-PTT padi diKecamatan Kalasan. Faktor-faktor yang diduga berhubungan dengan partisipasi petani, yaitu faktor internal, dimana faktor internal dari umur, pendidikan, sikap, dan motivasi. Sedangkan untuk faktor eksternal terdiri dari peran penyuluh, peran ketua kelompok tani, dan peran dari babinsa.

Untuk menguji hipotesis ini dengan menggunakan analisis Chi-square dengan menggunakan SPSS 22.0 for Windows. Pada analisis ini partisipasi sebagai variabel dependent, sedangkan umur, pendidikan, motivasi, sikap, peran penyuluh, peran ketua kelompok, dan peran babinsa sebagai variabel independent..

Faktor-faktor yang diduga berhubungan dengan partisipasi petani di Kecamatan Kalasan akan dibahas sesuai dengan hasil uji Chi-square berdasarkan yang tertera pada Tabel 6 .

Berdasarkan Tabel 6 dapat diketahui bahwa menggunakan analisis Chi-Square terdapat tiga variabel independent yang signifikan atau yang memiliki hubungan dengan variable dependent, sedangkan variabel independent yang lain tidak memiliki hubungan dengan variabel dependent dengan nilai signifikansi sebesar $10 \%(\alpha=0,1)$.

1. Umur

Berdasarkan Tabel 6 dapat diketahui bahwa nilai $\mathrm{x}^{2}$ hitung sebesar 0,768 lebih kecil dari $\mathrm{x}^{2}$ tabel yaitu 2,706, $\mathrm{x}^{2}$ tabel didapat dengan melihat $\alpha=$ 0,1 dan df atau derajat bebas 1 . Hal ini menunjukkan bahwa Ho diterima dan Ha ditolak, sehingga tidak ada hubungan variabel umur dengan partisipasi petani dalam program GP-PTT padi. Selain itu, taraf signifikansi sebesar 0,381 lebih besar dari $\alpha=0,1$ yang artinya variabel umur tidak signifikan. Dengan demikian, variabel umur tidak berhubungan dengan partisipasi petani dalam program GP-PTT padi. 
Tabel 6. Hasil Analisis Chi-Square mengenai Faktor-faktor yang Berhubungan dengan Partisipasi Petani

\begin{tabular}{lcccc}
\hline \multirow{2}{*}{ Variabel } & \multicolumn{2}{c}{ Pearson Chi Square } & Sig & \multirow{2}{*}{ Ket } \\
\cline { 2 - 3 } & Hit & $\mathbf{( 0 , 1 , d f )}$ & & \\
\hline Umur & 0,768 & 2,706 & 0,381 & NS \\
Pendidikan & 7,803 & 4,605 & 0,020 & $*$ \\
Motivasi & 9,030 & 2,706 & 0,003 & $*$ \\
Sikap & 6,494 & 2,706 & 0,011 & $*$ \\
Peran Penyuluh & 0,260 & 2,706 & 0,610 & NS \\
Peran Ketua Kelompok Tani & 0,017 & 2,706 & 0,897 & NS \\
Peran Babinsa & 1,047 & 2,706 & 0,306 & NS \\
\hline
\end{tabular}

Keterangan*Signifikasi: $\alpha=0,1$

NS Non-signifikan

Ho ditolak $=\mathrm{x}^{2}$ hit $>\mathrm{x}^{2}(0,1, \mathrm{df})$

Ho diterima $=\mathrm{x}^{2}$ hit $<\mathrm{x}^{2}(0,1, \mathrm{df})$

\section{Pendidikan}

Berdasarkan tabel 6 dapat diketahui bahwa nilai $\mathrm{x}^{2}$ hitung sebesar 7,803 lebih besar dari $x^{2}$ tabel yaitu $4,605, x^{2}$ tabel didapat dengan melihat $\alpha$ $=0,1$ dan df atau derajat bebas 2 . Hal ini menunjukkan bahwa Ho ditolak dan Ha diterima, sehingga ada hubungan variabel pendidikan dengan partisipasi petani dalam program GP-PTT padi. Selain itu, taraf signifikansi sebesar 0,020 lebih kecil dari $\alpha=0,1$ yang artinya variabel pendidikan signifikan. Dengan demikian, variabel pendidikan berhubungan dengan partisipasi petani dalam program GP- PTTpadi

\section{Motivasi}

Berdasarkan Tabel 6 dapat diketahui bahwa nilai $x^{2}$ hitung sebesar 9,030 lebih besar dari $x^{2}$ tabel yaitu $2,706, x^{2}$ tabel didapat dengan melihat $\alpha=0,1$ dan df atau derajat bebas 1. Hal ini menunjukkan bahwa Ho ditolak dan Ha diterima, sehingga ada hubungan variabel motivasi dengan partisipasi petani dalam program GP-PTT padi. Selain itu, taraf signifikansi sebesar 0,003 lebih kecil dari $\alpha=0,1$ yang artinya variabel motivasi signifikan. Dengan demikian, variabel motivasi berhubungan dengan partisipasi petani dalam program GP-PTT padi.

\section{Sikap}

Berdasarkan Tabel 6 dapat diketahui bahwa nilai $\mathrm{x}^{2}$ hitung sebesar 6,494 lebih besar dari $\mathrm{x}^{2}$ tabel yaitu $2,706, \mathrm{x}^{2}$ tabel didapat dengan melihat $\alpha=0,1$ dan $\mathrm{df}$ atau derajat bebas 1 . Hal ini menunjukkan bahwa Ho ditolak dan $\mathrm{Ha}$ diterima, sehingga ada hubungan variabel sikap dengan partisipasi petani dalam program GP-PTT padi. Selain itu, taraf signifikansi 
sebesar 0,011 lebih kecil dari $\alpha=0,1$ yang artinya variabel sikap signifikan. Dengan demikian, variabel sikap berhubungan dengan partisipasi petani dalam program GP-PTT padi.

\section{Peran Penyuluh}

Berdasarkan Tabel 6 dapat diketahui bahwa nilai $\mathrm{x}^{2}$ hitung sebesar 0,260 lebih kecil dari $\mathrm{x}^{2}$ tabel yaitu $2,706, \mathrm{x}^{2}$ tabel didapat dengan melihat $\alpha=0,1$ dan df atau derajat bebas 1 . Hal ini menunjukkan bahwa Ho diterima dan Ha ditolak, sehingga tidak ada hubungan variabel peran penyuluh dengan partisipasi petani dalam program GP-PTT padi. Selain itu, taraf signifikansi sebesar 0,610 lebih besar dari $\alpha=0,1$ yang artinya variabel peran penyuluh tidak signifikan. Dengan demikian, variabel peran penyuluh tidak berhubungan dengan partisipasi petani dalam program GP-PTT padi.

\section{Peran Ketua Kelompok Tani}

Berdasarkan Tabel 6 dapat diketahui bahwa nilai $\mathrm{x}^{2}$ hitung sebesar 0,017 lebih kecil dari $\mathrm{x}^{2}$ tabel yaitu $2,706, \mathrm{x}^{2}$ tabel didapat dengan melihat $\alpha=0,1 \mathrm{dan}$ df atau derajat bebas 1 . Hal ini menunjukkan bahwa Ho diterima dan Ha ditolak, sehingga tidak ada hubungan variabel peran ketua kelompok tani dengan partisipasi petani dalam program GP- PTT padi. Selain itu, taraf signifikansi sebesar 0,897 lebih besar dari $\alpha=0,1$ yang artinya variabel peran ketua kelompok tani tidak signifikan. Dengan demikian, variabel peran ketua kelompok tani tidak berhubungan dengan partisipasi petani dalam program GP- PTT padi

\section{Peran Babinsa}

Berdasarkan Tabel 6 dapat diketahui bahwa nilai $\mathrm{x}^{2}$ hitung sebesar 1,047 lebih kecil dari $\mathrm{x}^{2}$ tabel yaitu $2,706, \mathrm{x}^{2}$ tabel didapat dengan melihat $\alpha=0,1$ dan df atau derajat bebas 1 . Hal ini menunjukkan bahwa Ho diterima dan Ha ditolak, sehingga tidak ada hubungan variabel peran babinsa dengan partisipasi petani dalam program GP-PTT padi. Selain itu, taraf signifikansi sebesar 0,306 lebih besar dari $\alpha=0,1$ yang artinya variabel peran babinsa tidak signifikan. Dengan demikian, variabel peran babinsa tidak berhubungan dengan partisipasi petani dalam program GP-PTT padi.

Chi-square memiliki kelemahan yaitu tidak mengetahui keeratan hubungan antara variabel-variabel yang diuji. Dengan demikian untuk menanggulanginya dapat digunakan suatu perhitungan koefisien kontingensi (C) secara sederhana sebagai uji lanjut dari Ch-square. Koefisien kontingensi dapat mengetahui arah hubungan positif dan negatif sehingga untuk mengetahui keeratan hubungan dan mengetahui arah hubungan uji Gamma. Hasil uji Gamma dapat dilihat pada Tabel 7. 
Tabel 7. Hasil Uji Gamma Mengenai Keeratan Hubungan Faktor-Faktor yang Berhubungan

\begin{tabular}{llcc}
\hline \multicolumn{2}{c}{ dengan Partisipasi Petani di Kecamatan Kalasan } & & \\
\hline \multicolumn{1}{c}{ Variabel } & Ordinal Gamma & Sig & Ket \\
\hline Pendidikan & 0,611 & 0,003 & $*$ \\
Motivasi & 0,881 & 0,023 & $*$ \\
Sikap & 0,843 & 0,055 & $*$
\end{tabular}

Keterangan :

* signifikan $\alpha=0,1$

0,00 sampai 0,09 tidak ada hubungan

0,10 sampai 0,29 hubungan positif lemah

0,30 sampai 0,49 hubungan positif lemah moderat 0,50 sampai 0,69

hubungan positif agak kuat

0,70 sampai 0,89 hubungan positif kuat 0,90 sampai 1 hubungan positif

sangat kuat

$-0,10$ sampai $-0,29$ hubungan negatif lemah

$-0,30$ sampai $-0,49$ hubungan negatif lemah moderat

$-0,50$ sampai $-0,69$ hubungan negatif agak kuat

$-0,70$ sampai -0,89 hubungan negatif kuat

-0,90 sampai -1 hubungan negatif sangat kuat

Sumber : Analisis Data Primer Tahun 2015

Berdasarkan Tabel 7 dapat diketahui bahwa taraf signifikansi variabel pendidikan melalui uji gamma sebesar 0,003 lebih kecil dari taraf signifikansi $\alpha=0,1$. Hal ini menunjukkan bahwa variabel pendidikan memiliki hubungan dengan partisipasi petani dalam program GP-PTT padi di Kecamatan Kalasan. Selain itu, nilai ordinal gamma yang didapat pada variabel pendidikan sebesar 0,611. Hal ini menunjukkan bahwa keeratan hubungan pada interval 0,50 0,69 yang artinya ada hubungan agak kuat antara pendidikan dan partisipasi. Kemudian arah hubungan diantara dua variabel ini adalah positif yang artinya peningkatan pada pendidikan akan diikuti dengan peningkatan partisipasi petani dalam program GP-PTT padi di Kecamatan Kalasan. Sehingga hipotesis umur memiliki hubungan yang kuat dengan partisipasi petani dalam program GP-PTT padi di Kecamatan Kalasan diterima.

Berdasarkan Tabel 7 dapat diketahui bahwa taraf signifikansi variabel motivasi melalui uji gamma sebesar 0,023 lebih kecil dari taraf signifikansi $\alpha=0,1$. Hal ini menunjukkan bahwa variabel motivasi memiliki hubungan dengan partisipasi petani dalam program GP-PTT padi di Kecamatan Kalasan. Selain itu, nilai ordinal gamma yang didapat pada variabel motivasi sebesar 0,881. Hal ini menunjukkan bahwa 
keeratan hubungan pada interval $0,70-0,89$ yang artinya ada hubungan kuat antara motivasi dan partisipasi. Kemudian arah hubungan diantara dua variabel ini adalah positif yang artinya peningkatan motivasi akan diikuti dengan peningkatan partisipasi petani dalam program GP-PTT padi di Kecamatan Kalasan. Sehingga hipotesis motivasi petani memiliki hubungan yang kuat dengan partisipasi petani dalam program GP-PTT padi di Kecamatan Kalasan diterima.

Kemudian selanjutnya berdasarkan Tabel 7 dapat diketahui bahwa taraf signifikansi variabel sikap melalui uji gamma sebesar 0,055 lebih kecil dari taraf signifikansi $\alpha=0,1$. Hal ini menunjukkan bahwa variabel sikap memiliki hubungan dengan partisipasi petani dalam program GP-PTT padi di Kecamatan Kalasan. Selain itu, nilai ordinal gamma yang didapat pada variabel sikap sebesar 0,843. Hal ini menunjukkan bahwa keeretan hubungan pada interval 0,700,89 yang artinya ada hubungan kuat antara sikap dan partisipasi. Kemudian arah hubungan diantara dua variabel ini adalah positif yang artinya peningkatan sikap akan diikuti dengan peningkatan partisipasi petani dalam program GP-PTT padi di Kecamatan Kalasan. Sehingga hipotesis sikap memiliki hubungan yang kuat dengan partisipasi petani dalam program GP-PTT padi di Kecamatan Kalasan diterima.

\section{KESIMPULAN DAN SARAN}

\section{Kesimpulan}

1. Secara umum partisipasi petani sudah termasuk tinggi dalam program GPPTT padi di Kecamatan Kalasan.

2. Secara keseluruhan petani memiliki partisipasi tertinggi pada partisipasi eksekusi dengan capaian sebesar95,41\%.

3. Faktor-faktor yang berhubungan dengan partisipasi petani dalam program GP-PTT padi di Kecamatan Kalasan, Kabupaten Sleman adalah pendidikan, motivasi, dan sikap.

a. Pendidikan memiliki hubungan positif agak kuat, yang artinya peningkatan pendidikan petani diikuti dengan peningkatan partisipasi petani dalam program GP-PTT padi.

b. Motivasi memiliki hubungan positif kuat, yang artinya peningkatan motivasi petani diikuti dengan peningkatan partisipasi petani dalam program GP-PTT padi.

c. Sikap memiliki hubungan positif kuat, yang artinya peningkatan sikap petani diikuti dengan peningkatan partisipasi petani dalam program GP-PTT padi.

4. Faktor-faktor yang tidak berhubungan dengan partisipasi petani dalam program GP- PTT padi di Kecamatan Kalasan, Kabupaten Sleman adalah umur, peran penyuluh, peran ketua kelompok, dan peran babinsa. 


\section{Saran}

1. Perlunya peningkatan partisipasi petani pada aspek inisiasi (perencanaan) dan legitimasi (pengambilan keputusan) dalam program GP-PTT padi karena tahap ini merupakan tahap awal sebelum program GPPTT padi dilaksanakan. Petani harus memberikan partisipasinya pada tahapinisiasi dan legitimasi supaya pada saat pelaksanaan dapat berjalan dengan baik dan sesuai dengan yang diharapkan. Partisipasi petani pada tahap inisiasi dan legitimasi lebih rendah dari tahap eksekusi karena beberapa petani masih pasif dalam memberikan ide, masukan, dan pendapatnya. Oleh karena itu, perlunya peran ketua kelompok dalam memotivasi anggota kelompoknya untuk mengeluarkan ide atau pendapatnya dalam setiap kegiatan/pertemuan kelompok. Hal ini disebabkan karena ketua kelompok lebih dekat dan intensitas untuk bertemu dengan anggota kelompoknya lebih sering daripada penyuluh.

2. Partisipasi petani pada motivasi mengenai kreativitas mengembangkan teknologi baru dalam GP-PTT padi dapat diperkuat dengan aktif mengikuti penyuluhan dan aktif berdiskusi dengan penyuluh.

3. Partisipasi petani pada sikap mengenai menerapkan program GP-PTT padi jika ada bantuan pemerintah, dapat diperkuat dengan aktif mengikuti penyuluhan dan sharing dengan penyuluh untuk mengetahui keuntungan dari program GP-PTT pagi.

4. Untuk meningkatkan partisipasi petani dapat meningkatkan pendidikan melalui pendidikan non formal seperti mengikuti penyuluhan danpelatihanpelatihan.

\section{DAFTAR PUSTAKA}

Hanafi, H., Soemardjo Soemardjo, Amirudin Saleh, dan Ida Yuhana. 2004. Pendekatan Model Komunikasi, Partisipasi Kelompok dalam Adopsi Inovasi Agribisnis Ternak Kambing PE di Girikerto-Sleman, Daerah Istimewa Yogyakarta. Agro Ekonomi 11 (2) : 70-81.

Irawan, E. Prospek Partisipasi Petani dalam Program Pembangunan Hutan Rakyat untuk Mitigasi Perubahan Iklim di Wonosobo. Jurnal Ekonomi Pembangunan 12 (1) : 67-76.

Mikkelsen, B., 2003. Metode Penelitian Partisipatoris dan Upaya - Upaya Pemberdayaan. Jakarta : Yayasan Obor Indonesia

Muchtar, Karmila, Ninuk Purnaningsih dan Djoko Susanto. 2014. Komunikasi Partisipatif pada Sekolah Lapangan Pengelola an Tanaman Terpadu (SL-PTT). Jurnal Komunikasi Pembangunan 12 (2) : 1-14.

Nazir, M. 1988. Metode Penelitian. Jakarta: Gahlia Indonesia. 
Agro Ekonomi Vol. 27/No. 1, Juni 2016

Toha. 2007. Produktivitas Padi

Sawah di Kecamatan Kebasen

Gogo Melalui Penerapan

Kabupaten Banyumas. Jurnal

Pengelolaan Tanaman SEPA 9 (1) : 34-4.

Terpadu dengan introduksi

Varietas Unggul. Jurnal

Penelitian Pertanian Tanaman

Pangan 26 (3) : 180-187.

Watemin, dkk. 2012 .

Penerapan Pengelolaan

Tanaman Terpadu (PTT) Padi

Winata, Adi dan Ernik Yuliana. 2012.

Tingkat Partisipasi Petani Hutan dalam Program Pengelolaan Hutan Bersama Masyarakat (PHBM)

Perhutani. Jurnal MIMBAR XXVIII (1) : 65-76. 